\title{
Reproductive seasonality and sperm cryopreservation in the male tufted deer
}

\section{(Elaphodus cephalophus)}

Saritvich Panyaboriban ${ }^{\mathrm{a}, \mathrm{c}}$, Ram Pratap Singh ${ }^{\mathrm{a}, \mathrm{d}}$, Nucharin Songsasen ${ }^{\mathrm{a}}$, Luis Padilla ${ }^{\mathrm{b}}$,

Janine Brown ${ }^{\mathrm{a}}$, Dolores Reed ${ }^{\mathrm{a}}$, Mongkol Techakumphu ${ }^{\mathrm{c}}$, Budhan Pukazhenthi ${ }^{\mathrm{a}, \mathrm{e}}$

${ }^{\mathrm{a} S m i t h s o n i a n ~ C o n s e r v a t i o n ~ B i o l o g y ~ I n s t i t u t e, ~ N a t i o n a l ~ Z o o l o g i c a l ~ P a r k, ~ F r o n t ~ R o y a l, ~ V A, ~}$ 22630 USA

${ }^{\mathrm{b}}$ Saint Louis Zoo, St. Louis, MO, 63110, USA

${ }^{c}$ Department of Obstetrics, Gynaecology and Reproduction, Faculty of Veterinary Science,

Chulalongkorn University, Bangkok, 10330, Thailand

${ }^{\mathrm{d}}$ Sálim Ali Centre for Ornithology and Natural History, Anaikatty 641 108, Coimbatore, India

${ }^{\mathrm{e}}$ Corresponding author. Email: pukazhenthib@si.edu

Running title: Tufted deer sperm crypreservation

(C) 2016. This manuscript version is made available under the Elsevier user license 


\section{Abstract}

The tufted deer is a small deer, listed as near threatened on the IUCN Red List, and there is no information on the fundamental reproductive biology of this species. In this study, we report for the first-time, characterization of male reproductive traits and cryopreservation of semen in this species. Males were subjected to electroejaculation during each season (autumn, winter, spring, and summer), and ejaculates were assessed for motility and quality traits. Fecal samples were collected $3-5$ times weekly for 2 years and analyzed for androgen metabolites using enzyme immunoassay. Ejaculates with $>70 \%$ motility were cryopreserved using Beltsville extender (BF5F) or Triladyl ${ }^{\circledR}$. Straws were thawed and assessed subjectively as well as swim-up processed to isolate motile spermatozoa for CASA analysis and acrosome integrity at hourly interval. Tufted deer male reproductive and semen traits peaked in autumn. Mean fecal androgen concentrations were highest in the summer compared to baseline values during rest of the year. Sperm motility and acrosome integrity were lower immediately after thawing in both cryodiluents compared with raw ejaculates. Motility characteristics following swim-up were higher in BF5F compared with Triladyl. Four hour after thawing, both percent sperm motility and progression declined further and were similar between BF5F and Triladyl. However, the proportion of spermatozoa with intact acrosomal membranes was higher in BF5F than Triladyl. Results indicate that tufted deer exhibit seasonal variations in reproductive traits and that $\mathrm{BF} 5 \mathrm{~F}$ better preserves sperm motility and acrosomal integrity after cryopreservation compared with Triladyl.

Keywords: cervid, testosterone, semen, cryodiluents, CASA 


\section{Introduction}

The tufted deer (Elaphodus cephalophus) is listed as 'near threatened' on the IUCN Red List [1]. Morphologically, the tufted deer is small deer, and all four subspecies (E.c.cephalophus, E.c.michianus, E.c.ichangensis, and E.c.forciensus) inhabit large areas of southern China and some areas in northern Myanmar [2]. Although tufted deer is not included in the list of the Convention on International Trade in Endangered Species (CITES), the species is listed as Vulnerable in the Chinese Red List [3], highlighting current threats to their survival. Their habitat overlaps with the giant panda (Ailuropoda melanoleuca), and are found in forested regions at $300-4,500$ meters above sea level in proximity to water sources [4]. Within Asia, extensive habitat destruction and over hunting have led to a rapid decline in their population numbers [5]. Historically, studies on tufted deer have focused primarily on population distribution and habitat in the wild $[2,6-8]$ and a small number of studies have examined population genetics [9-12].

In North America, tufted deer were first exhibited at the San Diego Zoo. The founding population was comprised of three males (from China) and two females (one each from China and Germany) imported in 1985. Currently there are 38 males and 28 females distributed among 18 institutions in the United States. Similar to many other ungulate species, tufted deer populations in captivity also have been slowly declining due to a lack of interest in this species. The calculated current gene diversity of the extant population is $\sim 70 \%$ and classified as a Yellow Species Survival Plan (SSP) program by the Association of Zoos and Aquariums, meaning that the population cannot retain $90 \%$ gene diversity for 10 generations [13]. Population modeling predicts that without a further infusion of founder animals, the ex situ populations gene diversity would decline to $\sim 57 \%$ in 100 years. Therefore, the tufted deer SSP 
plans to increase the number of exhibit spaces and ensure animals are provided an opportunity to breed to better manage this species ex situ. Long term management of small populations involve an interplay between maintaining gene diversity and minimizing inbreeding insubsequent generations. At present the ex situ breeding program has relied on natural breeding; however, when natural reproduction fails, it is important to implement reproductive technologies including semen cryopreservation and artificial insemination to facilitate reproduction between behaviorally incompatible animals and efficiently move germplasm among geographically isolated populations. Development of artificial insemination technologies warrants a thorough understanding of species-specific reproductive biology. However, there is a lack of fundamental information on the reproductive biology of tufted deer as well as the impact of season on male reproduction.

Seasonal changes in semen and reproductive parameters have previously been reported in many mammalian species, for example the ram [14, 15], Eld's deer (Rucervus eldi thamin, [16]), roe deer (Capreolus capreolus, [17]), red deer (Cervus elaphus, [18]), (pampas deer (Ozotocerus bezoarticus, [19]), and American bison (Bison bison bison, [20]). Tufted deer typically breed from September through December and fawn in April to July [4]. Males also exhibit seasonal antler growth and rutting behavior - barking by males [4]. In other cervids, additional physical/morphometric changes such as changes in neck girth, scrotal circumference and ejaculate quality also have been reported [18-20]. Hence it is also important to examine the influence of season on tufted deer reproductive.

Spermatozoa from several species of deer including the Eld's deer, fallow deer (Dama dama), spotted deer (Axis axis), and red deer (Cervus elaphus) have been successfully cryopreserved and live offspring produced via artificial insemination [21-25]. However, sperm 
cryopreservation remains a challenge in numerous species. Major challenges to sperm cryopreservation include minimizing the toxic effects of cryoprotectants, limiting intracellular ice crystal formation and osmotic stress during freezing and thawing [26, 27]. Selection of an appropriate cryoprotectant relies on sperm membrane permeability properties as well as choice of usage temperature. To our knowledge, there is no information on semen cryopreservation in tufted deer.

Therefore, the overall objectives of this study were to i) assess seasonal changes in reproductive traits including physical characteristics, hormonal and ejaculate traits and ii) examine the cryosensitivity of tufted deer sperm to two different cryodiluents.

\section{Materials and Methods}

All chemicals used in the present study were purchased from Sigma-Aldrich Chemical Company (Sigma, St. Louis, MO, USA), unless stated otherwise. Animal procedures were reviewed and approved by the Animal Care and Use Committee at the Smithsonian Conservation Biology Institute (SCBI). This study was carried out from July 2008 to June 2010 at SCBI near Front Royal, Virginia $\left(78.17^{\circ} \mathrm{W}, 38.88^{\circ} \mathrm{N}\right)$ and the Wildlife Conservation Society, Bronx Zoo, Bronx, New York $\left(73.88^{\circ} \mathrm{W}, 40.85^{\circ} \mathrm{N}\right)$.

\subsection{Animals}

Five mature males (age range, $1-15 \mathrm{y}$; body weight, $16.8-21.8 \mathrm{~kg}$; $1-2$ ejaculate per male per season; 24 ejaculates) were examined over the three year study period. Animals were housed individually in roofed and open-sided shelter (approximately $10 \times 11 \mathrm{~m}$ ) under natural environmental conditions (Front Royal, VA). Animal were maintained on 300 g/day/animal of 
17\% protein herbivore diet (Mazuri ${ }^{\circledR}$ ADF-16, Land O'Lakes, Inc., Arden Hills, MN), 10 high fiber biscuits (Marion Leaf Eater Biscuits, Gorilla Sized, Marion Zoological Foods, Plymouth, $\mathrm{MN}$ ), $100 \mathrm{~g} /$ day/animal of mixed produce (fresh sweet potatoes, turnips, carrots and kale; $25 \mathrm{~g}$ each) for three times a week, and ad libitum water.

Animals at the Bronx Zoo ( $\mathrm{n}=2$ males; used only for sperm cryopreservation studies) were housed with one or two females with an offspring in a $10 \times 7 \mathrm{~m}$ corral with a $7 \times 3 \mathrm{~m}$ three-sided heated shelter or in a 4,000 $\mathrm{m}^{2}$ wooded exhibit with a $9 \times 3 \mathrm{~m}$ three-sided heated shelter. Each animal received $300 \mathrm{~g} /$ day/animal of $14 \%$ protein and $23 \%$ fiber herbivore diet (ADF-25 Herbivore, Mazuri), alfafa/timothy mixed hay ad libitum, $170 \mathrm{~g}$ of legume hay, $25 \mathrm{~g}$ kale, $40 \mathrm{~g}$ yam, and water ad libitum.

All animals were provided routine preventive and clinical veterinary care.

\subsection{Anesthesia and Morphometric Measurements}

Males were anesthetized by intramuscular injections using a combination of azaperone (0.15- $0.3 \mathrm{mg} / \mathrm{kg}$; ZooPharm, Laramie, WY), butorphanol tartrate $(0.15-0.2 \mathrm{mg} / \mathrm{kg}$;

Equanol; Vedco Inc, St. Joseph, MO) and medetomine hydrochloride $(0.025-0.03 \mathrm{mg} / \mathrm{kg}$; ZooPharm, Laramie, WY) with ketamine hydrochloride (1 - 2 mg/kg; Vedco Inc, St. Joseph, MO). After recumbency, endotracheal intubation was performed to facilitate positive pressure ventilation, and a light plane of anesthesia was maintained with intravenous boluses of propofol $(0.2-2.0 \mathrm{mg} / \mathrm{kg}$ per bolus, slowly administered to effect into the cephalic vein at an average rate of $0.029 \mathrm{mg} / \mathrm{kg} / \mathrm{min}$; PropoFlo; Abbott Animal Health, Abbott Park, IL). Upon completion of procedures, anesthesia was antagonized with intramuscular injections of 
atipamezole $(0.125-0.15 \mathrm{mg} / \mathrm{kg}$; Pfizer Animal Health / Zoetis, New York, NY) and naltrexone $(1.5-2.0 \mathrm{mg} / \mathrm{kg}$; ZooPharm, Laramie, WY).

Testicular length and width were determined using scientific calipers (Scienceware; Sci-Art Product, Pequannock, NJ). Testicular volume was calculated using the formula $\left(\right.$ Volume $=\frac{4}{3} \pi\left(\frac{\text { Testicular length }}{2}\right)\left(\frac{\text { Testicular width }}{2}\right)^{2} ;$ [28]). Scrotal circumference and neck girth were measured using a measuring tape [18].

\subsection{Semen Collection and Evaluation}

For semen collection, the rectum was evacuated using lubricated gloved fingers and the prepuce was cleaned using $0.9 \%$ saline solution and wiped dry with cotton gauze. Then a sine-wave electrostimulator (AC $60 \mathrm{~Hz}$; P.T. Electronics, Boring, OR) and a lubricated Teflon probe $(2.0 \mathrm{~cm}$ diameter) was used to administer $80-100$ electrical stimulations in three series while incrementally increasing the stimulation voltage (range, $2-6 \mathrm{~V}$ ) as previously described by Howard [29]. Electrical stimulations consisted of three series: 2, 3, 4V (10 stimulations each); 3, 4, 5V (10 stimulations each); and 3, 4, 5V (10 stimulations each), respectively. Between series, animals were rested and ejaculates examined for volume, $\mathrm{pH}$ ( $\mathrm{pH}$ - indicator strips; EMD Millipore Corporation, Billerica, MA), osmolality (Wescor Inc, Logan UT), sperm motility and forward progressive status (scale $0-5 ; 5=$ best; [29]). Each ejaculate was then transferred into sterile $15 \mathrm{~mL}$ screw-capped centrifuge tubes (Fisher Scientific) and maintained at $37^{\circ} \mathrm{C}$ in a water-bath. Upon completion of semen collection, raw semen with similar motility characterisitcs were pooled into a single tube, then a $20-30 \mu \mathrm{L}$ aliquot was added to $500 \mu \mathrm{L}$ of $0.3 \%$ glutaraldehyde in phosphate-buffered saline $(\mathrm{pH} 7.4$; $340 \mathrm{mOsm}$ ) for sperm morphology assessment (Supplemental Material S1). Twenty 
microliters of semen also was fixed in $500 \mu \mathrm{L}$ of $4 \%$ paraformaldehyde (USB Corporation, Cleveland, $\mathrm{OH}$ ) for acrosomal membrane assessment using Coomassie Brilliant Blue staining (Supplemental Material S2).

\subsection{Semen Cryopreservation}

Ejaculated semen samples with $>70 \%$ initial motility were used in this study.

Ejaculates from each donor was subdivided into two aliquots for cryopreservation in Beltsville extender (BF5F; [30]) versus Triladyl ${ }^{\circledR}$ (Minitüb GmbH, Tiefenbach, Germany). BF5F diluent consisted of $20 \%(\mathrm{vol} / \mathrm{vol})$ egg yolk, $1.6 \%(\mathrm{wt} / \mathrm{vol})$ glucose, $1.6 \%(\mathrm{wt} / \mathrm{vol})$ fructose, $1.2 \%$ (wt/vol) Tes (N-tris[hydroxymethyl]methyl-2-aminoethanesulfonic acid), $0.2 \%(\mathrm{wt} / \mathrm{vol})$ tris (Tris[hydroxymethyl]aminomethane), 1,000 i.u. penicillin $\mathrm{G}$ per $\mathrm{mL}, 1,000 \mu \mathrm{g}$ streptomycin sulfate per $\mathrm{mL}$, and $0.5 \%$ ( $\mathrm{vol} / \mathrm{vol}$ ) surfactant mixture of sodium and triethanolamine lauryl sulfate (Orvus ES Paste; Equex, Nova Chemical Sales Inc., Scitaute, MA). Triladyl consisted of a proprietory mixture of tris, citric acid, fructose, glycerol, antibiotics, and 20\% egg yolk. For cryopreservation in BF5F, semen samples were diluted with BF5F (without glycerol) to $300-400 \times 10^{6}$ sperm per $\mathrm{mL}$ in $15-\mathrm{mL}$ centrifuge tubes. The tubes were placed in a waterbath $\left(500 \mathrm{~mL} ; 25^{\circ} \mathrm{C}\right)$ that was transferred to a walk-in cold room. When the water bath reached $5^{\circ} \mathrm{C}$, an equal volume of pre-cooled $\mathrm{BF5F}$ containing $8 \%$ (vol/vol) glycerol was added in three steps (added $1 / 4$ volume and incubated for 15 min, added another $1 / 4$ volume and incubated for $15 \mathrm{~min}$; and then added the remaining diluent) to achieve a final concentration of $4 \%$ glycerol (vol $/ \mathrm{vol})$. Extended semen samples were then aspirated into labeled $0.5 \mathrm{~mL}$ French straws (AgTech Inc, Manhattan, KS) and heat-sealed. Straws were cryopreserved using a two-step method. Briefly, straws were placed $8 \mathrm{~cm}$ above liquid nitrogen for $1 \mathrm{~min}$ in 
a styrofoam cooler, then moved to $3 \mathrm{~cm}$ above liquid nitrogen for $1 \mathrm{~min}$ and plunged into liquid nitrogen.

For cryopreservation in Triladyl, egg yolk (20\% vol/vol) was added to Fraction A per manufacturer's instruction and the ejaculates were diluted 3:1 (semen:diluent) at ambient temperature $\left(25^{\circ} \mathrm{C}\right)$ with Triladyl containing $12 \%$ glycerol to achieve $4 \%$ (vol/vol) glycerol concentration. Diluted sperm suspension was loaded into labeled $0.5 \mathrm{~mL}$ French straws, heat sealed, and placed inside a zip-loc plastic bag that was then placed inside a water jacket (500 $\mathrm{mL} ; 25^{\circ} \mathrm{C}$ ), cooled to $5^{\circ} \mathrm{C}$ (over a period of $3 \mathrm{~h}$ ) and cryopreserved as described above.

\subsection{Semen Thawing, Assessment and Swim-Up Processing}

After at least 12 mo of storage, two straws per extender per ejaculate were randomly selected and thawed $\left(30 \mathrm{~s}, 37^{\circ} \mathrm{C}\right)$. Following thawing, sperm total motility was assessed subjectively using a phase-contrast microscope (200x; Olympus BX41; Olympus, Japan). Sperm morphology and acrosomal membrane integrity were examined as described earlier. In order to assess sperm motility characteristics using Computer-Assisted Sperm Analysis (CASA; Hamilton Thorne Research, Beverly, MA), thawed aliquots were subjected to swimup processing. Briefly, immediately after thawing the sperm suspension was transferred to a $1.5 \mathrm{~mL}$ centrifuge tube and centrifuged $(300 \times g$ for $10 \mathrm{~min})$ to pellet the sperm. The supernatant was carefully removed and discarded. One-hundred $\mu \mathrm{L}$ of warm TALP (Tyrodes Albumin Lactate Pyruvate) comprising of $\mathrm{NaCl}(6.2 \mathrm{~g} / \mathrm{L}), \mathrm{KCl}(0.23 \mathrm{~g} / \mathrm{L}), \mathrm{CaCl}_{2} \cdot 2 \mathrm{H}_{2} \mathrm{O}(0.39$ $\mathrm{g} / \mathrm{L}), \mathrm{MgCl}_{2} \cdot 6 \mathrm{H}_{2} \mathrm{O}(0.01 \mathrm{~g} / \mathrm{L}) \mathrm{NaHCO}_{3}(2.1 \mathrm{~g} / \mathrm{L}), \mathrm{Na}_{2} \mathrm{HPO}_{4}(0.05 \mathrm{~g} / \mathrm{L}), \mathrm{Na}$ lactate $(0.13 \%$, vol/vol), Na pyruvate (0.02 g/L) and BSA (6 g/L); osmolarity 295 mOsm and pH 7.5 [31] was carefully layered over the sperm pellet and incubated $\left(37^{\circ} \mathrm{C} ; 30 \mathrm{~min}\right)$ to allow motile sperm to 
swim up into the medium. The supernatant was then removed and transferred into a fresh centrifuge tube. Sperm suspensions were evaluated for motility characteristics using CASA at 0 (within 5 min after swim-up processing), 1, 2, 3, and $4 \mathrm{~h}$. Briefly, two $\mu \mathrm{L}$ of sperm suspension was placed on a prewarmed $4 \mathrm{X}$ - CELL chamber slide (Cytonix, Beltsville, MD; $20 \mu \mathrm{m}$ depth). At least 10 microscopic fields were evaluated using CASA to analyze sperm total motility, forward progressive motility and sperm motion characteristics including straight-line velocity (VSL, $\mu \mathrm{m} / \mathrm{s}$ ); curvilinear velocity (VCL, $\mu \mathrm{m} / \mathrm{s}$ ); average path velocity (VAP, $\mu \mathrm{m} / \mathrm{s})$; straightness (STR = VSL/VAP, \%), linearity $(\mathrm{LIN}=\mathrm{VSL} / \mathrm{VCL}, \%)$; amplitude of lateral head displacement (ALH), and beat cross frequency (BCF). CASA established setup parameters were as follows: frame capture speed rate, $60 \mathrm{~Hz}$; cell size (min/max), 21/33 $\mu \mathrm{m}^{2}$; threshold straightness, $80 \%$; VAP cut off, $20 \mu \mathrm{m} / \mathrm{s}$; and VSL cut off, $30 \mu \mathrm{m} / \mathrm{s}$. Sperm acrosomal integrity was assessed at hourly interval (for up to $4 \mathrm{~h}$ ) as described earlier.

\subsection{Fecal Sample Collection and Analysis of Fecal Androgen Metabolites}

Fecal samples were collected three to five times per wk for at least 18 mo. Fecal pellets were processed and hormone metabolites extracted as previously described by Brown et al.([32]; Supplement Material S3).

\subsection{Statistical Analyses}

All statistical analyses were carried out using Statistical Analysis System (SAS) package version 9.2 (SAS 9.2, SAS Institute Inc., Cary, NC). The year was divided into four seasons: autumn (September - November), winter (December - February), spring (March May), and summer (June - August) per the National Oceanic and Atmospheric Administration 
(USA). Data on seasonal effects on semen, hormonal and reproductive parameters were analyzed using GLM procedures. Season was considered as a fixed - crossed effect, whereas the male (donor) was set as a random effect. PROC Univariate of SAS was used to test normal distribution of the data. Non-normal data (concentration, total number of sperm, progressive motility, $\mathrm{pH}$, volume, acrosomal integrity and $\mathrm{BCF}$ ) were subjected to log transformation, confirmed for normal distribution and analyzed using GLM. Progressive motility, pH, ejaculate volume, and acrosomal integrity could not be normalized and hence analyzed using the Wilcoxon rank - sum test (PROC NPAR1WAY of SAS).

For post - thaw analyses, data were compared by two - way ANOVA with Tukey multiple comparisons test to detect difference across treatments. All $P$ values lower than 0.05 were considered statistically significant.

Data presented represents mean \pm SEM unless specified otherwise.

\section{Results}

\subsection{Seasonal changes in gross morphometry and seminal traits}

Mean neck girth was highest $(P<0.05)$ in the autumn $(\mathrm{Q} 1$ (median) Q3; $42.0(44.0)$ $44.0 \mathrm{~cm}$ ) compared to that during other seasons (Q1 (median) Q3; $37.0(39.0) 43.0 \mathrm{~cm}$ ), as was testicular length $(P<0.05$; Table 1$)$. The average ratio between testicular length and width also was the highest in autumn. Scrotal circumference, testicular width and testicular volume were unaffected $(P>0.05)$ by season.

Table 2 summarizes seasonal changes in fresh ejaculated semen. Spermic ejaculates were obtained from all males via electroejaculation. Sperm total motility, forward progressive motility and the percentage of spermatozoa with an intact acrosome were higher $(P<0.05)$ in 
autumn (September - November) but decreased through the winter and spring. Ejaculate volume also was highest in autumn (Q1 (median) Q3; $0.5(0.9) 1.6 \mathrm{~mL})$ compared to other seasons $(P<0.05)$. Mean ejaculate osmolality was $316.6 \pm 7.6 \mathrm{mOsm}(\mathrm{Q} 1$ (median) $\mathrm{Q} 3 ; 301.0$ (315.5) 340.0 mOsm; Table 2) with a pH of 7.6 (Q1 (median) Q3; 7.3 (7.9) 8.1; Table 2) and not affected by season.

There was no effect of season on percentages of morphologically normal sperm $(P>$ 0.05 ; Table 2). The predominant sperm defect in raw ejaculates was a bent midpiece with a cytoplasmic droplet (approximately 15.0\%), and the incidence was higher $(P<0.05)$ in summer compared to spring (Table 2).

\subsection{Fecal androgen patterns}

Overall mean concentration of fecal androgens was $1.04 \pm 0.09 \mu \mathrm{g} / \mathrm{g}$ (mean $\pm \mathrm{SD}$ ). Seasonal changes in mean fecal androgen concentrations for individual animals, as well as all combined, are shown in Figure 1. Mean androgen concentrations reached peak values in summer $(1.21 \pm 0.04 \mu \mathrm{g} / \mathrm{g})$ and gradually declined through rest of the year (autumn, $1.16 \pm$ $0.04 \mu \mathrm{g} / \mathrm{g}$; winter, $1.03 \pm 0.02 \mu \mathrm{g} / \mathrm{g}$; and spring, $1.06 \pm 0.02 \mu \mathrm{g} / \mathrm{g}$ ).

\subsection{Semen cryopreservation}

Over half of ejaculates ( $\mathrm{n}=14 / 25 ; 56 \%)$ exhibited $<70 \%$ total sperm motility, $<250$ million total spermatozoa or urine contamination and were not used for cryopreservation in this study. The influence of cryodiluents on sperm motility and acrosomal integrity is depicted in Table 3. Freeze-thawing resulted in a sharp $(P<0.05)$ decline in sperm motility (BF5F, 54.9\%; Triladyl, 70.0\%) compared with raw semen (76.7\%). However, there were no 
differences in sperm total motility, proportion of morphologically normal sperm or the percentage of spermatozoa with intact acrosomal membranes immediately after thawing. Swim-up processing improved overall sperm motility in both BF5F $(P<0.05)$ and Triladyl $(P$ $<0.01$ ) extenders compared with post-thawed semen suspensions (Table 3). Although there was no difference in the proportion of morphologically normal sperm between cryodiluents following swim-up, ejaculates cryopreserved in BF5F exhibited a higher $(P<0.05)$ proportion of spermatozoa with an intact acrosomal membrane compared with Triladyl. Swim-up processing of spermatozoa cryopreserved in Triladyl also yielded the lowest proportion of spermatozoa with a bent neck compared to immediately after thawing $(P<0.05$; Table 3$)$. Sperm kinetics parameters (CASA analysis) are summarized in Table 4. After swimup processing, recovered sperm in both groups were incubated $\left(37^{\circ} \mathrm{C}\right)$ and evaluated for sperm traits (motility and forward progression) and kinetic parameters (VAP, VCL, VSL, LIN, STR, ALH, and BCF) by CASA. Aliquots also were analyzed for acrosomal integrity using Coomassie Brilliant Blue staining. At $0 \mathrm{~h}$ of incubation following swim-up processing, spermatozoa cryopreserved in BF5F exhibited a higher $(P<0.05) \%$ motility, \%forward progression, \%intact acrosome, VSL, LIN, and STR when compared with Triladyl (Figure 2A-C and Table 4). Sperm motility and forward progression increased in spermatozoa cryopreserved in BF5F after $1 \mathrm{~h}$ compared with $0 \mathrm{~h}$ at $37^{\circ} \mathrm{C}$ and then declined with time $(2,3$, and $4 \mathrm{~h})$. At $4 \mathrm{~h}$, sperm motility and forward progression declined $(P<0.05)$ rapidly in aliquots cryopreserved in BF5F compared with 1 and $2 \mathrm{~h}$ time intervals. Acrosomal membrane integrity in both diluents (BF5F and Triladyl) was reduced immediately after thawing. Moreover, cryopreservation in BF5F resulted in a significantly higher $(P<0.05)$ proportion of 
spermatozoa with an intact acrosomal membrane compared with Triladyl at all-time points examined (Figure 2C).

\section{Discussion}

As the first systematic characterization of male reproductive biology of the tufted deer, we chacterized ejaculate traits, fecal androgen metabolite patterns, and identified a cryodiluent that consistently yielded $>35 \%$ post-thaw sperm motility after cryopreservation. Similar to a number of other deer species, season exerted a significant effect on physical morphometry, semen traits and fecal androgen metabolite concentrations. Amongst the two cryodiluents evaluated, spermatozoa cryopreserved in BF5F consistenly yielded better sperm motility, forward progression, sperm kinetic parameters, and acrosomal integrity. Overall, this 1) represents novel information on the male reproductive biology of the tribe Muntiacini, which consists of two genera, Elaphodus and Muntiacus [33] and 2) denotes the first steps toward establishment of sperm banks and development of assited reproductive technologies for improved genetic management of the tufted deer.

Seasonal changes in gross morphometry, ejaculate characteristics and androgen concentrations have been reported in the red deer [34], axis deer [35], fallow deer [36] and Eld's deer [16]. In the tufted deer, testicular length, scrotal circumference, and neck girth were greatest in the autumn however, there was no influence of season on total testicular volume or scrotal circumference. Likewise, the average ratio between testicular length and width was the highest in autumn. In the domestic bull, males with greater testicular length:width ratio and higher scrotal circumference have been reported to produce more sperm in their ejaculates [37]. Moreover, testicular length also is positively correlated with better semen traits and 
breeding season in the ram [38], stallion [39] and human [40, 41]. A positive correlation between testicular size and neck girth was reported in the axis deer [35], fallow deer [36, 42], and the Eld's deer [16]. Previous reports in fallow and red deer also have suggested that neck girth is a reliable indicator of male reproductive performance [18, 36, 43, 44]. Thus, our results are in agreement with previoius findings in other species, and may be useful in monitoring reproductive performance of male tufted deer.

Collection of spermic ejaculates from cervids is routinely achived via electroejaculation $[15,25,45]$, and in few cases using an artificial vagina [46]. Tufted deer males are highly fractious, so collection via the latter approach is likely impractical. In the present study, we demonstrated that electroejaculation is a safe and effective method for semen collection under anesthesia. Spermic ejaculates were obtained from all males evaluated, but the ejaculate quality was highly variable. Tufted deer males yield ejaculates characterized by small volume $(1.2 \pm 0.2 \mathrm{~mL})$, high sperm concentration $\left(396.5 \pm 160.7 \times 10^{6}\right.$ spermatozoa $/ \mathrm{mL})$, and a moderate percentage of motile spermatozoa $(57.0 \pm 3.8 \%)$. These results are comparable to previous reports on sambar deer [47], fallow deer [48] and Iberian red deer $[45,49]$. The influence of exposure to females on overall ejaculate quality has previously been reported in the pampas deer [19]. Since males in the present study were housed with females (Bronx Zoo) or separate from female but with olfactory communication (SCBI), the effect of females on overall ejaculate quality cannot be ruled out. Furthermore, these differences in management also could have contributed to the observed variation in ejaculate quality. Mean semen $\mathrm{pH}$ and osmolality were $7.6 \pm 0.1$ and $316.6 \pm 7.6 \mathrm{mOsm}$, respectively, and was influenced by male-male variation. The variation among males observed in this study may be attributed to differences in contributions from the accessory sex glands or 
the extent of relaxation achieved with the anesthetic protocols described above and warrants further study. Season also exerted a strong influence on tufted deer seminal traits. Electroejaculates contained higher proportions of motile and forward progressive spermatozoa in autumn compared with winter, spring or summer. A similar pattern also has previously been reported in several other mammals including the ram [50], stallions [51] and deer [23].

Although spermic ejaculates were collected during all seasons, there was a high incidence of sperm pleiomorphisms, particularly spermatozoa with a bent midpiece and a cytoplasmic droplet and spermatozoa with a proximal cytoplasmic droplet. Ejaculates also contained a higher (not significant) proportion of detached heads during winter and spring. Presence of cytoplasmic droplets in ejaculates is often considered an evidence of dysfuction in epididymal maturation or accessory sex glands resulting in abnormal spermatogenesis [52]. Seasonal variations in sperm pleiomorphisms also has been reported in other seasonally breeding mammals, especially during testicular regression in the non-breeding season (Eld's deer [21], fallow deer [48], and ram [50]). Lincoln [18] reported that presence of morphologically abnormal spermatozoa in ejaculates in rams could be an indirect consequence of seasonal fluctuations in gonadotrophin and testosterone secretions. In the present study, ejaculates contained a slightly higher proportion of abnormal spermatozoa in the non-breeding season coincident with lower fecal androgen concentrations but was not statistically significant. However, the percentage of abnormal spermatozoa did not differ among seasons. In seasonal breeding cervids, initiation of spermatogenesis occurs several months prior to peak breeding season $[53,54]$. This pattern was most closely mirrored in Iberian red deer and Cantabrian chamois $[55,56]$. Based on behavioral observations (Dolores Reed, personal 
communication), hormone concentrations, and seminal traits, it is clear that autumn represents the peak breeding season for the tufted deer.

Abnormalities in sperm morphology also have been correlated with reduced fertility or infertility in various species, including humans [57], bulls [58], and boars [59]. Among the various structural compartments of a spermatozoon, the acrosome is considered vital in part due to it's involvement is sperm-oocyte binding and fertilization [60]. In the present study, the proportion of spermatozoa with an intact acrosome reached a nadir during the winter compared to the other three seasons. Acrosomal abnormalities have been implicated in compromised fertility in various species [61-64], the impact of high proportions of abnormal acrosomes as well as other abnormalities on tufted deer fertility warrants further studies.

Semen cryopreservation is possibly the most useful tool available to preserve the male genome of rare and endangered species [23, 65-69]. When combined with other assisted reproductive technologies (ART; i.e. artificial insemination, AI; in vitro embryo production, IVP; semen sexing; intracytoplasmic sperm injection, ICSI), sperm cryopreservation permits effective genetic management of non-domestic species managed in captivity [70-72]. To our knowledge this is the first report of semen cryopreservation in the tufted deer or any other species in the tribe Muntiacini. In the present study, ejaculates were processed for cryopreservation without seminal plasma removal, an approach often used in cervids. A limitation of our study was that there was no information on the actual composition of Triladyl since it was a commercial product. Between BF5F and Triladyl, several components including egg yolk, fructose, and tris were similar although their propotions could have been different except for egg yolk (20\% vol/vol). In contrast, BF5F contained an additional buffering agent, TES (N-tris(hydroxymethyl)methyl-2-aminoethanesulfonic acid) with a pKa of 7.4 (closer to 
physiological $\mathrm{pH}$ ). During cryopreservation, spermatozoa exterience sharp changes in $\mathrm{pH}$ and TES included in BF5F could have provided improved protection against $\mathrm{pH}$ fluctuations and thereby preserved a higher proportion of viable sperm after freeze-thawing. Furthermore, citric acid was only present in Triladyl. An earlier study on buffalo sperm cryopreservation reported that tris-based extenders improved freezability of buffalo spermatozoa inclucing improved post-thaw motility, acrosomal integrity, and in vivo fertility compared with citric acid based extenders $[73,74]$. Therefore, in the present study, our results could have been influenced by a number of factors either alone or acting synergistically and warrant further analyses of individual components on post-thaw sperm viability, motility and acrosomal integrity.

Although there were some differerences in the composition of the cryodiluents used in the present study, glycerol was the sole permeating cryoprotectant. Glycerol is one of the most commonly used cryoprotectants for preserving sperm from domestic and non-domestic species [75-78]. Immediately after thawing, both post-thaw semen groups induced a decline in the proportion of motile spermatozoa (subjective motility assessment; $54.9 \%$ and $70.0 \%$ loss in BF5F and Triladyl, respectively, when compared with freshly ejaculated semen). Since most of the samples were above the threshold concentration permissible for CASA analysis, thawed aliquots were centrifuged and swim-up processed in TALP. Centrifugation and swimup processing was not detrimental to tufted deer sperm motility. Following swim-up, BF5F consistently yielded a higher proportion of spermatozoa with good motility and forward progression. Swim-up processing failed to improve the overall proportion of morphologically normal spermatozoa, but the proportion of spermatozoa with a bent neck was significantly reduced in aliquots cryopreserved in Triladyl. Despite the decline in sperm motility, 
spermatozoa from tufted deer appear to be relatively resistant to freeze-thawing induced damage. Swim-up sperm progressive motility and longevity are influenced by a number of factors including media composition (relative concentrations of energy susbtrates), incubation temperature, osmolality, and type and concentration of cryoprotectant [79]. The proportion of subjectively motile spermatozoa was higher after swim up processing in both BF5F and Triladyl. Similar to previous studies, swim-up processing reduced the number of sperm recovered in the supernant $[31,80]$. It is plausible that other sperm separation methods, including density gradient centrifugation, may improve the proportion of motile sperm, the number of sperm recovered, as well as sperm morphology [81, 82]. CASA motility, forward progression, and kinetic parameters of swim-up spermatozoa were higher in BF5F than Triladyl at all time intervals evaluated. However, sperm motility, progressive motility, and velocity declined sharply over $4 \mathrm{~h}$ of in vitro incubation in TALP. These results may have resulted from depletion of energy substrates to support sperm motility because the only energy substrate in TALP was pyruvate. Pyruvate and lactate (also a component of TALP) also have been shown to induce capacitation and acrosome reaction in spermatozoa [83, 84]. These factors could have contributed to hyperactivation changes (high motility and forward progression) as well as motility parameters including VSL, LIN and STR) observed in aliquots immediately after swim-up processing. This was also accompanied by a concomitant sharp decline in the proportion of spermatozoa with an intact acrosomal membrane. Although TALP has been used for in vitro incubation of spermatozoa from various species, our results suggest that further studies are warranted to optimize in vitro culture conditions for tufted deer spermatozoa. These improvement also could facilitate the development of in vitro embryo production protocols for the tufted deer. 
In conclusion, the present study is the first detailed analysis of male reproductive characteristics, androgen profiles, and semen cryopreservation in the tufted deer. Our findings reveal that it is possible to collect spermic ejaculates from captive tufted deer using electroejaculation, and cryodiluents used for cryopreserving spermatozoa in other cervids also protects tufted deer sperm from freeze-thawing induced damage. This new knowledge has immense practical value with respect to developing assisted reproductive technologies including establishment of a genome resource bank and artificial inseminaton for enhanced genetic management of this near threatened species $[85,86]$.

\section{Acknowledgements}

The authors thank Dr. Katharine Hope and Lisa Ware for their outstanding veterinary support. We also thank Dr. David Powell, Curator of Mammals, and the Veterinary staff of the Wildlife Conservation Society, Bronx Zoo, NY for their support (providing access to collection animals and veterinary coverage). We also like to thank the Smithsonian Conservation Biology Institute's animal management staff (Allyson O’Neil), endocrine technician (Sarah Putman), and interns (Rebecca Bacon and Jonathan Prilubda) for their assistance with animal care and hormone analyses. Research was funded by Sichel Endowment Fund. Panyaboriban was supported by Royal Golden Jubliee-PhD-industrial link program, Thailand Research Fund (PHD/0365/2551). Ram Pratap Singh was supported by the Fulbright-Nehru grant (1942/FNPDR/2014).

\section{References}

[1] Harris RB, Jiang Z. Elaphodus cephalophus. The IUCN Red LIst of Threatened Species. 2015; Version 2015.2. (www.iucnredlist.org). 
[2] Ohtaishi N, Gao Y. A review of the distribution of all species of deer (Tragulidae, Moschidae and Cervidae) in China. Mamm Rev. 1990;20:125-44.

[3] Smith AT, Xie Y, Hoffmann RS, Lunde D, MacKinnon J, Wilson DE, et al. A guide to the mammals of China: Princeton University Press; 2010.

[4] Nowak RM. Walker's Mammals of the World. 6th ed. Baltimore, Maryland The Johns Hopkins University Press; 1999.

[5] Heffelfinger JR, Hewitt DG. Taxonomy, evolutionary history, and distribution. In: Hewitt D, editor. Biology and management of white-tailed deer. Boca Raton, FL, USA: Taylor \& Francis Group; 2011. p. 3-39.

[6] Zhang Z, Wei F, Li M, Zhang B, Liu X, Hu J. Microhabitat separation during winter among sympatric giant pandas, red pandas, and tufted deer: the effects of diet, body size, and energy metabolism. Can J Zool. 2004;82:1451-8.

[7] Houji S, Helix L. Distribution, habits and resource status of the tufted deer (Elaphodus cepholophus). Acta Zool Sin. 1982;28:307-11.

[8] Li X, Buzzard P, Jiang X. Habitat associations of four ungulates in mountain forests of southwest China, based on camera trapping and dung counts data. Popul Ecol. 2014;56:251-6.

[9] Cao X, Jiang H, Zhang X. Polymorphic karyotypes and sex chromosomes in the tufted deer (Elaphodus cephalophus): cytogenetic studies and analyses of sex chromosome-linked genes. Cytogenet Genome Res. 2004;109:512-8.

[10] Shi L, Yang F, Kumamoto A. The chromosomes of tufted deer (Elaphodus cephalophus). Cytogenet Genome Res. 1991;56:189-92.

[11] Yuze Z, Xiran W, Jianhua C. Somatic chromosome studies of the Tufted deer (Elaphodus cephalophus). Zool Res. 1983;1:16.

[12] Zhang W, Cao X, Shen Q, Liu W, Ni S, Hua X, et al. Isolation and characterization of the Cetn1 gene from tufted deer (Elaphodus cephalophus). Biochem Genet. 2008;46:652-62.

[13] Castillo S. Western tufted deer (Elaphodus cephalophus) AZA species survival plan yellow program. AZA species survival plan coordinator \& studbook keeper. 2014.

[14] Karagiannidis A, Varsakeli S, Karatzas G. Characteristics and seasonal variations in the semen of Alpine, Saanen and Damascus goat bucks born and raised in Greece.

Theriogenology. 2000;53:1285-93.

[15] García-Macías V, Martínez-Pastor F, Álvarez M, Borragan S, Chamorro CA, Soler AJ, et al. Seasonal changes in sperm chromatin condensation in ram (Ovis aries), Iberian red deer (Cervus elaphus hispanicus), and brown bear (Ursus arctos). J Androl. 2006;27:837-46. [16] Monfort SL, Brown JL, Bush M, Wood TC, Wemmer C, Vargas A, et al. Circannual inter-relationships among reproductive hormones, gross morphometry, behaviour, ejaculate characteristics and testicular histology in Eld's deer stags (Cervus eldi thamin). J Reprod Fertil. 1993;98:471-80.

[17] Goeritz F, Quest M, Wagener A, Fassbender M, Broich A, Hildebrandt T, et al. Seasonal timing of sperm production in roe deer: interrelationship among changes in ejaculate parameters, morphology and function of testis and accessory glands. Theriogenology. 2003;59:1487-502.

[18] Lincoln GA. The seasonal reproductive changes in the red deer stag (Cervus elaphus). J Zool. 1971;163:105-23.

[19] Villagrán M, Ungerfeld R. Permanent contact with females increases testosterone and improves fresh semen traits in pampas deer (Ozotoceros bezoarticus) males. Anim Reprod Sci. 2013;143:85-90. 
[20] Krishnakumar S, Whiteside D, Elkin B, Thundathil J. Effect of reproductive seasonality on gamete quality in the North American Bison (Bison bison bison). Reprod Domest Anim. 2015;50:206-13.

[21] Monfort SL, Asher GW, Wildt DE, Wood TC, Schiewe MC, Williamson LR, et al. Successful intrauterine insemination of Eld's deer (Cervus eldi thamin) with frozen-thawed spermatozoa. J Reprod Fertil. 1993;99:459-65.

[22] Asher GW, Kraemer DC, Magyar SJ, Brunner M, Moerbe R, Giaquinto M. Intrauterine insemination of farmed fallow deer (Damadama) with frozen-thawed semen via laparoscopy. Theriogenology. 1990;34:569-77.

[23] Umapathy G, Sontakke SD, Reddy A, Shivaji S. Seasonal variations in semen characteristics, semen cryopreservation, estrus synchronization, and successful artificial insemination in the spotted deer (Axis axis). Theriogenology. 2007;67:1371-8.

[24] Haigh JC, Bowen G. Artificial insemination of red deer (Cervus elaphus) with frozenthawed wapiti semen. J Reprod Fertil. 1991;93:119-23.

[25] Asher GW, Berg DK, Evans G. Storage of semen and artificial insemination in deer. Anim Reprod Sci. 2000;62:195-211.

[26] Medeiros CMO, Forell F, Oliveira ATD, Rodrigues JL. Current status of sperm cryopreservation: why isn't it better? Theriogenology. 2002;57:327-44.

[27] Parks JE, Graham JK. Effects of cryopreservation procedures on sperm membranes. Theriogenology. 1992;38:209-22.

[28] Howard JG, Brown JL, Bush M, Wildt DE. Teratospermic and Normospermic Domestic Cats: Ejaculate Traits, Pituitary-Gonadal Hormones, and Improvement of Spermatozoal Motility and Morphology After Swim-Up Processing. J Androl. 1990;11:204-15.

[29] Howard JG. Semen collection and analysis in carnivores. J Zoo Wildl Med. 1993;3:3909.

[30] Howard JG, Bush M, De Vos V, Schiewe MC, Pursel VG, Wildt DE. Influence of cryoprotective diluent on post-thaw viability and acrosomal integrity of spermatozoa of the African elephant (Loxodonta africana). J Reprod Fertil. 1986;78:295-306.

[31] Parrish JJ, Krogenaes A, Susko-Parrish JL. Effect of bovine sperm separation by either swim-up or Percoll method on success of in vitro fertilization and early embryonic development. Theriogenology. 1995;44:859-69.

[32] Brown JL, Terio KA, Graham LH. Fecal androgen metabolite analysis for noninvasive monitoring of testicular steroidogenic activity in felids. Zoo Biology. 1996;15:425-34.

[33] Cap H, Aulagnier S, Deleporte P. The phylogeny and behaviour of Cervidae (Ruminantia Pecora). Ethol Ecol Evol. 2002;14:199-216.

[34] Suttie JM, Lincoln GA, Kay RNB. Endocrine control of antler growth in red deer stags. J Reprod Fertil. 1984;71:7-15.

[35] Loudon ASI, Curlewis JD. Cycles of antler and testicular growth in an aseasonal tropical deer (Axis axis). J Reprod Fertil. 1988;83:729-38.

[36] Asher GW, Peterson AJ, Bass JJ. Seasonal pattern of LH and testosterone secretion in adult male fallow deer, Dama dama. J Reprod Fertil. 1989;85:657-65.

[37] Bailey TL, Monke D, Hudson RS, Wolfe DF, Carson RL, Riddell MG. Testicular shape and its relationship to sperm production in mature Holstein bulls. Theriogenology.

1996;46:881-7. 
[38] Boland MP, Al-Kamali AA, Crosby TF, Haynes NB, Howles CM, Kelleher DL, et al. The influence of breed, season and photoperiod on semen characteristics, testicular size, libido and plasma hormone concentrations in rams. Anim Reprod Sci. 1985;9:241-52.

[39] Kavak A, Lundeheim N, Aidnik M, Einarsson S. Testicular measurements and daily sperm output of Tori and Estonian breed stallions. Reprod Domest Anim. 2003;38:167-9. [40] Sakamoto H, Saito K, Oohta M, Inoue K, Ogawa Y, Yoshida H. Testicular volume measurement: comparison of ultrasonography, orchidometry, and water displacement. Urology. 2007;69:152-7.

[41] Arai T, Kitahara S, Horiuchi S, Sumi S, Yoshida K-i. Relationship of testicular volume to semen profiles and serum hormone concentrations in infertile Japanese males. Int J Fertil Womens Med. 1997;43:40-7.

[42] Rolf HJ, Fischer K. Serum testosterone, 5- $\alpha$-dihydrotestosterone and different sex characteristics in male fallow deer (Cervus dama): a long-term experiment with accelerated photoperiods. Comparative Biochemistry and Physiology Part A: Physiology. 1996;115:20721.

[43] Field RA, Young OA, Asher GW, Foote DM. Characteristics of male fallow deer muscle at a time of sex-related muscle growth. Growth. 1984;49:190-201.

[44] Lincoln GA, Fraser HM, Fletcher TJ. Induction of early rutting in male red deer (Cervus elaphus) by melatonin and its dependence on LHRH. J Reprod Fertil. 1984;72:339-43. [45] Martínez-Pastor F, Martínez F, Alvarez M, Maroto-Morales A, García-Alvarez O, Soler A, et al. Cryopreservation of Iberian red deer (Cervus elaphus hispanicus) spermatozoa obtained by electroejaculation. Theriogenology. 2009;71:628-38.

[46] Gizejewski Z. Improving the artificial vagina for the separation of fractions in the ejaculate of red deer. Anim Sci Pap Rep. 2000;18:145-51.

[47] Cheng FP, Wu JT, Chan JPW, Wang JS, Fung HP, Colenbrander B, et al. The effect of different extenders on post-thaw sperm survival, acrosomal integrity and longevity in cryopreserved semen of Formosan Sika deer and Formosan Sambar deer. Theriogenology. 2004;61:1605-16.

[48] Gosch B, Fischer K. Seasonal changes of testis volume and sperm quality in adult fallow deer (Dama dama) and their relationship to the antler cycle. J Reprod Fertil. 1989;85:7-17. [49] Martínez AF, Martínez-Pastor F, Álvarez M, Fernández-Santos MR, Esteso MC, De Paz $\mathrm{P}$, et al. Sperm parameters on Iberian red deer: electroejaculation and post-mortem collection. Theriogenology. 2008;70:216-26.

[50] Karagiannidis A, Varsakeli S, Alexopoulos C, Amarantidis I. Seasonal variation in semen characteristics of Chios and Friesian rams in Greece. Small Rumin Res. 2000;37:125-30.

[51] Janett F, Thun R, Niederer K, Burger D, Hässig M. Seasonal changes in semen quality and freezability in the Warmblood stallion. Theriogenology. 2003;60:453-61.

[52] Cooper TG, Yeung CH. Acquisition of volume regulatory response of sperm upon maturation in the epididymis and the role of the cytoplasmic droplet. Microsc Res Tech. 2003;61:28-38.

[53] Schön J, Blottner S. Estrogens are involved in seasonal regulation of spermatogenesis and sperm maturation in roe deer (Capreolus capreolus). Gen Comp Endocrinol. 2008;159:257-63. [54] Blottner S, Hingst O, Meyer H. Seasonal spermatogenesis and testosterone production in roe deer (Capreolus capreolus). J Reprod Fertil. 1996;108:299-305.

[55] Gizejewski Z. Effect of season on characteristics of red deer (Cervus elaphus L.) semen collected using modified artificial vagina. Reprod Biol. 2004;4:51-66. 
[56] Martinez-Pastor F, Guerra C, Kaabi M, Garcia-Macias V, de Paz P, Alvarez M, et al. Season effect on genitalia and epididymal sperm from Iberian red deer, roe deer and Cantabrian chamois. Theriogenology. 2005;63:1857-75.

[57] Zini A, Defreitas G, Freeman M, Hechter S, Jarvi K. Varicocele is associated with abnormal retention of cytoplasmic droplets by human spermatozoa. Fertil Steril. 2000;74:4614.

[58] Thundathil J, Palasz AT, Barth AD, Mapletoft RJ. The use of in vitro fertilization techniques to investigate the fertilizing ability of bovine sperm with proximal cytoplasmic droplets. Anim Reprod Sci. 2001;65:181-92.

[59] Althouse GC. Cytoplasmic droplets on boar sperm cells. JSwine Health Prod. 1998;6:128.

[60] Abou-Haila A, Tulsiani DRP. Mammalian sperm acrosome: formation, contents, and function. Arch Biochem Biophys. 2000;379:173-82.

[61] Menkveld R, Rhemrev JP, Franken DR, Vermeiden JP, Kruger TF. Acrosomal morphology as a novel criterion for male fertility diagnosis: relation with acrosin activity, morphology (strict criteria), and fertilization in vitro. Fertil Steril. 1996;65:637-44.

[62] Tardif S, Laforest JP, Cormier N, Bailey JL. The importance of porcine sperm parameters on fertility in vivo. Theriogenology. 1999;52:447-59.

[63] Rodriguez-Martinez H, Eriksson B, Lundeheim N. Freezing boar semen in flat plastic bags membrane integrity and fertility. Reprod Domest Anim. 1995;31:161-8.

[64] Nasr-Esfahani MH, Razavi S, Tavalaee M. Failed fertilization after ICSI and spermiogenic defects. Fertil Steril. 2008;89:892-8.

[65] Gilmore JA, McGann LE, Ashworth E, Acker JP, Raath JP, Bush M, et al. Fundamental cryobiology of selected African mammalian spermatozoa and its role in biodiversity preservation through the development of genome resource banking. Anim Reprod Sci. 1998;53:277-97.

[66] Fickel J, Wagener A, Ludwig A. Semen cryopreservation and the conservation of endangered species. Eur J Wildl Res. 2007;53:81-9.

[67] Prieto MT, Sanchez-Calabuig MJ, Hildebrandt TB, Santiago-Moreno J, Saragusty J. Sperm cryopreservation in wild animals. Eur J Wildl Res. 2014;60:851-64.

[68] Comizzoli P, Holt WV. Recent advances and prospects in germplasm preservation of rare and endangered species. In: Holt WV, Brown JL, Comizzoli P, editors. Reproductive Sciences in Animal Conservation: Springer; 2014. p. 331-56.

[69] Pukazhenthi BS, Togna GD, Padilla L, Smith D, Sanchez C, Pelican K, et al. Ejaculate traits and sperm cryopreservation in the endangered Baird's tapir (Tapirus bairdii). J Androl. 2011;32:260-70.

[70] Wiidt DE. Genetic resource banks for conserving wildlife species: justification, examples and becoming organized on a global basis. Anim Reprod Sci. 1992;28:247-57.

[71] Holt WV, Bennett PM, Volobouev V, Watwon PF. Genetic resource banks in wildlife conservation. J Zool. 1996;238:531-44.

[72] Roldan ERS, Gomendio M, Garde JJ, Espeso G, Ledda S, Berlinguer F, et al. Inbreeding and reproduction in endangered ungulates: preservation of genetic variation through the organization of genetic resource banks. Reprod Domest Anim. 2006;41:82-92.

[73] Dhami A, Kodagali S. Freezability, enzyme leakage and fertility of buffalo spermatozoa in relation to the quality of semen ejaculates and extenders. Theriogenology. 1990;34:853-63. 
[74] Dhami A, Jani V, Mohan G, Sahni K. Effect of extenders and additives on freezability, post thaw thermo-resistance and fertility of frozen Murrah buffalo semen under tropical climate. Buffalo J. 1994;10:35-45.

[75] Mantovani R, Rota A, Falomo ME, Bailoni L, Vincenti L. Comparison between glycerol and ethylene glycol for the cryopreservation of equine spermatozoa: semen quality assessment with standard analyses and with the hypoosmotic swelling test. Reprod Nutr Dev. 2002;42:217-26.

[76] Si W, Zheng P, Li Y, Dinnyes A, Ji W. Effect of glycerol and dimethyl sulfoxide on cryopreservation of rhesus monkey (Macaca mulatta) sperm. Am J Primatol. 2004;62:301-6. [77] Crosier AE, Pukazhenthi BS, Henghali JN, Howard J, Dickman AJ, Marker L, et al. Cryopreservation of spermatozoa from wild-born Namibian cheetahs (Acinonyx jubatus) and influence of glycerol on cryosurvival. Cryobiology. 2006;52:169-81. [78] Futino DO, Mendes MCB, Matos WNL, Mondadori RG, Lucci CM. Glycerol, Methyl-Formamide and Dimethyl-Formamide in Canine Semen Cryopreservation. Reprod Domest Anim. 2010;45:214-20.

[79] Watson PF. The causes of reduced fertility with cryopreserved semen. Anim Reprod Sci. 2000;60:481-92.

[80] Younglai EV, Holt D, Brown P, Jurisicova A, Casper RF. Sperm swim-up techniques and DNA fragmentation. Hum Reprod. 2001;16:1950-3.

[81] Chen MJ, Bongso A. Comparative evaluation of two density gradient preparations for sperm separation for medically assisted conception. Hum Reprod. 1999;14:759-64.

[82] Mortimer D. Sperm preparation methods. J Androl. 2000;21:357-66.

[83] Rogers BJ, Yanagimachi R. Retardation of guinea pig sperm acrosome reaction by glucose: the possible importance of pyruvate and lactate metabolism in capacitation and the acrosome reaction. Biol Reprod. 1975;13:568-75.

[84] O'Flaherty C, Breininger E, Beorlegui N, Beconi MT. Acrosome reaction in bovine spermatozoa: role of reactive oxygen species and lactate dehydrogenase C4. Biochim Biophys Acta Gen Subj. 2005;1726:96-101.

[85] Wildt DE. Genome resource banking for wildlife research, management, and conservation. ILAR J. 2000;41:228-34.

[86] Pukazhenthi BS, Wildt DE. Which reproductive technologies are most relevant to studying, managing and conserving wildlife? Reprod Fertil Dev. 2003;16:33-46. 


\section{Figure Legends:}

Figure 1. Mean $\pm(\mathrm{SEM})$ fecal androgen concentrations in male tufted deer (Elaphadus cephalophus) on the basis of season (Autumn, September - November; Winter, December February; Spring, March- May; and Summer, June - August). Values are mean \pm standard error of mean (SEM) for all males. Bars with different superscripts are significantly different across seasons $(P<0.05)$. The dashed line represents the overall mean androgen concentration.

Figure 2. Effect of swim-up processing tufted deer (Elaphadus cephalophus) semen cryopreserved in two different extenders, BF5F (-ø-) and Triladyl ( $\cdots \cdots)$. (A) Sperm motility by CASA; (B) progressive motility; (C) intact acrosome. Values are mean \pm standard error of mean (SEM). Bars with capital letters indicate significant differences among time intervals ( $P$ $<0.05)$ and small letters indicate the significant differences between extender within a time interval $(P<0.05)$. 
Table 1. Reproductive traits across seasons in male tufted deer ((Elaphadus cephalophus, $\mathrm{N}$ =5).

\begin{tabular}{|c|c|c|c|c|}
\hline Parameters & Autumn ${ }^{1}$ & Winter ${ }^{1}$ & Spring $^{1}$ & Summer $^{1}$ \\
\hline \multicolumn{5}{|l|}{ Testicular size } \\
\hline \multicolumn{5}{|l|}{ Right } \\
\hline Length $(\mathrm{cm})$ & $4.74 \pm 0.2^{\mathrm{a}}$ & $4.33 \pm 0.2^{b}$ & $4.41 \pm 0.3^{\mathrm{b}}$ & $4.43 \pm 0.3^{\mathrm{ab}}$ \\
\hline Width $(\mathrm{cm})$ & $2.4 \pm 0.3$ & $2.3 \pm 0.1$ & $2.4 \pm 0.4$ & $2.5 \pm 0.4$ \\
\hline Volume $\left(\mathrm{cm}^{3}\right)$ & $14.3 \pm 3.4$ & $12.2 \pm 1.8$ & $13.1 \pm 3.9$ & $14.6 \pm 4.5$ \\
\hline \multicolumn{5}{|l|}{ Left } \\
\hline Length $(\mathrm{cm})$ & $4.9 \pm 0.2^{\mathrm{a}}$ & $4.6 \pm 0.3^{\mathrm{ab}}$ & $4.4 \pm 0.4^{\mathrm{b}}$ & $4.4 \pm 0.5^{b}$ \\
\hline Width $(\mathrm{cm})$ & $2.3 \pm 0.2$ & $2.2 \pm 0.2$ & $2.4 \pm 0.4$ & $2.5 \pm 0.5$ \\
\hline Volume $\left(\mathrm{cm}^{3}\right)$ & $13.6 \pm 3.0$ & $12.1 \pm 2.3$ & $13.8 \pm 5.5$ & $14.8 \pm 6.3$ \\
\hline Total testicular volume $\left(\mathrm{cm}^{3}\right)$ & $27.9 \pm 6.2$ & $24.3 \pm 4.0$ & $26.9 \pm 9.2$ & $29.4 \pm 10.8$ \\
\hline Scrotal circumference $(\mathrm{cm})$ & $11.9 \pm 1.2$ & $11.5 \pm 0.8$ & $11.7 \pm 1.4$ & $11.3 \pm 1.0$ \\
\hline Neck girth $(\mathrm{cm})$ & $43.2 \pm 2.9^{\mathrm{a}}$ & $39.0 \pm 1.6^{\mathrm{bc}}$ & $41.6 \pm 2.3^{a b}$ & $35.7 \pm 2.7^{\mathrm{c}}$ \\
\hline
\end{tabular}

Values represent mean $\pm \mathrm{SD}$.

${ }^{\mathrm{a}, \mathrm{b}, \mathrm{c}}$ Significant differences among groups $(P<0.05)$.

${ }^{1}$ Autumn (September - November), Winter (December - February), Spring (March- May), Summer (June - August) 
Table 2. Comparison of semen parameters among seasons in male tufted deer (Elaphadus cephalophus, $\mathrm{N}=5$ ).

\begin{tabular}{|c|c|c|c|c|}
\hline Parameters & Autumn $^{1,2}$ & Winter $^{1,2}$ & Spring ${ }^{1,3}$ & Summer $^{1,2}$ \\
\hline \multicolumn{5}{|l|}{ Semen qualities } \\
\hline Motility (\%) & $76.0 \pm 5.5^{\mathrm{a}}$ & $47.7 \pm 21.8^{b}$ & $50.6 \pm 15.2^{b}$ & $57.6 \pm 15.0^{\mathrm{ab}}$ \\
\hline Progressive motility ${ }^{4}$ & $3.5 \pm 0.0^{\mathrm{a}}$ & $3.2 \pm 0.3^{\mathrm{ab}}$ & $2.9 \pm 0.4^{\mathrm{b}}$ & $3.0 \pm 0.4^{\mathrm{b}}$ \\
\hline $\mathrm{pH}$ & $7.6 \pm 0.3$ & $7.5 \pm 0.7$ & $7.8 \pm 0.7$ & $7.6 \pm 0.9$ \\
\hline Osmolarity (mOsm/kg) & $310.8 \pm 24.7$ & $296.2 \pm 34.2$ & $333.4 \pm 25.8$ & $337.5 \pm 16.3$ \\
\hline Volume (ml) & $2.0 \pm 1.0$ & $1.6 \pm 1.7$ & $0.7 \pm 0.4$ & $0.6 \pm 0.5$ \\
\hline Concentration $\left(\mathrm{x} 10^{6}\right.$ spermatozoa/ml) & $207.6 \pm 216.4$ & $350.9 \pm 371.3$ & $591.1 \pm 1,223.0$ & $331.3 \pm 264.9$ \\
\hline Total sperm (x $10^{6}$ spermatozoa) & $529.6 \pm 821.2$ & $715.2 \pm 809.6$ & $677.0 \pm 1,525.7$ & $259.0 \pm 226.9$ \\
\hline \multicolumn{5}{|l|}{ Sperm morphology } \\
\hline Normal sperm (\%) & $34.2 \pm 10.2$ & $19.8 \pm 7.6$ & $31.8 \pm 9.6$ & $16.2 \pm 5.3$ \\
\hline Abnormal sperm $(\%)$ & $65.8 \pm 10.2$ & $80.2 \pm 7.6$ & $68.2 \pm 9.6$ & $83.8 \pm 5.3$ \\
\hline Microcephalic & $2.2 \pm 1.1$ & $5.8 \pm 3.0$ & $2.3 \pm 1.1$ & $6.3 \pm 2.7$ \\
\hline Tightly coiled tail & $6.4 \pm 0.9$ & $6.9 \pm 1.4$ & $8.0 \pm 3.4$ & $9.2 \pm 2.8$ \\
\hline Bent midpiece with droplet & $16.2 \pm 5.6^{\mathrm{ab}}$ & $17.7 \pm 4.7^{\mathrm{ab}}$ & $7.7 \pm 2.4^{\mathrm{a}}$ & $24.2 \pm 7.8^{\mathrm{b}}$ \\
\hline Bent midpiece & $4.0 \pm 1.3$ & $4.8 \pm 1.8$ & $3.7 \pm 1.5$ & $4.7 \pm 2.7$ \\
\hline Proximal droplet & $11.2 \pm 2.5$ & $12.9 \pm 4.5$ & $7.8 \pm 3.3$ & $14.7 \pm 5.1$ \\
\hline Distal droplet & $7.4 \pm 4.5$ & $6.1 \pm 3.8$ & $6.8 \pm 4.0$ & $3.6 \pm 3.0$ \\
\hline Detached head & $1.4 \pm 0.8$ & $17.8 \pm 10.2$ & $17.5 \pm 9.3$ & $7.9 \pm 2.8$ \\
\hline Others & $17.0 \pm 4.7$ & $8.2 \pm 2.6$ & $14.4 \pm 5.3$ & $13.2 \pm 4.2$ \\
\hline \multicolumn{5}{|l|}{ Acrosomal integrity } \\
\hline Intact acrosome $(\%)$ & $82.3 \pm 4.7^{\mathrm{a}}$ & $58.6 \pm 10.2^{\mathrm{b}}$ & $76.2 \pm 2.9^{\mathrm{ab}}$ & $77.8 \pm 2.9^{\mathrm{ab}}$ \\
\hline Damaged acrosome $(\%)$ & $6.7 \pm 1.3$ & $22.6 \pm 10.6$ & $7.6 \pm 1.1$ & $7.6 \pm 1.1$ \\
\hline Non-intact acrosome (\%) & $11.0 \pm 4.3$ & $18.8 \pm 4.3$ & $14.6 \pm 2.0$ & $14.6 \pm 2.0$ \\
\hline
\end{tabular}


Values represent mean \pm SD

${ }^{\mathrm{a}, \mathrm{b}, \mathrm{c}}$ Significant differences among groups $(P<0.05)$.

${ }^{1}$ Autumn (September - November), Winter (December - February), Spring (March- May),

Summer (June - August)

${ }^{2} \mathrm{~N}=5$ males; 1 ejaculate/male/season

${ }^{3} \mathrm{~N}=5$ males; total number of ejaculates $=9$

${ }^{4}$ Based on a scale 0 to $5 ; 5=$ best 
Table 3. Comparisons of post- thawed semen traits of tufted deer (Elaphadus cephalophus)

between two freezing extenders (BF5F vs. Triladyl) before and after swim-up processing.

\begin{tabular}{llcccccc}
\hline Group & Processing & $\begin{array}{c}\text { Subjective } \\
\text { motility } \\
(\%)\end{array}$ & $\begin{array}{c}\text { Normal } \\
\text { morphology } \\
(\%)\end{array}$ & $\begin{array}{c}\text { Abnormal } \\
\text { morphology } \\
(\%)\end{array}$ & $\begin{array}{c}\text { Intact } \\
\text { acrosome } \\
(\%)\end{array}$ & $\begin{array}{c}\text { Damaged } \\
\text { acrosome } \\
(\%)\end{array}$ & $\begin{array}{c}\text { Non-intact } \\
\text { acrosome } \\
(\%)\end{array}$ \\
\hline Pre-freeze & & $76.7 \pm 2.0$ & $49.5 \pm 9.1$ & $50.5 \pm 9.1$ & $74.3 \pm 4.0$ & $11.1 \pm 3.3$ & $14.6 \pm 2.0$ \\
BF5F & Post - thawed & $34.6 \pm 6.6^{\mathrm{A} *}$ & $52.0 \pm 6.4$ & $48.0 \pm 6.4$ & $34.7 \pm 2.9^{*}$ & $50.5 \pm 2.2^{*}$ & $14.8 \pm 2.2$ \\
& Swim - up & $53.9 \pm 7.4^{\mathrm{B} *}$ & $57.0 \pm 7.3$ & $43.0 \pm 7.3$ & $41.2 \pm 2.9^{\mathrm{a} *}$ & $52.2 \pm 2.5^{*}$ & $6.6 \pm 1.3^{\mathrm{a} *}$ \\
Triladyl & Post - thawed & $23.1 \pm 5.3^{\mathrm{A} *}$ & $52.2 \pm 5.7$ & $47.8 \pm 5.7$ & $29.1 \pm 2.4^{*}$ & $50.2 \pm 3.4^{*}$ & $20.8 \pm 2.5^{*}$ \\
& Swim - up & $47.8 \pm 6.5^{\mathrm{B} *}$ & $60.1 \pm 6.5$ & $39.9 \pm 6.5$ & $31.4 \pm 1.6^{\mathrm{b} *}$ & $47.0 \pm 7.7^{*}$ & $21.6 \pm 7.4^{\mathrm{b}}$ \\
\hline
\end{tabular}

Values represent mean \pm SEM.

${ }^{\mathrm{A}, \mathrm{B}}$ Significant difference between processing and same treatment $(P<0.05)$.

${ }^{\mathrm{a}, \mathrm{b}}$ Significant differences between treatment and same processing $(P<0.05)$.

* Significant differences when compared with pre-freeze sample $(P<0.05)$. 
Table 4. Mean ( \pm SEM) of sperm kinetic parameters (VAP, VCL, VSL, LIN, STR, ALH, and $\mathrm{BCF}$ ) in swim-up processed tufted deer (Elaphadus cephalophus) semen cryopreserved in BF5F and Triladyl at $0,1,2,3$, and $4 \mathrm{~h}$ of in vitro incubation.

\begin{tabular}{llccccc}
\hline Parameters & Treatments & \multicolumn{5}{c}{ Storage time (h) } \\
& & 0 & 1 & 2 & 3 & 4 \\
\hline VAP $(\mu \mathrm{m} / \mathrm{s})$ & BF5F & $77.1 \pm 4.2^{\mathrm{A}}$ & $77.0 \pm 5.1^{\mathrm{A}}$ & $72.5 \pm 3.5^{\mathrm{AB}}$ & $69.6 \pm 4.6^{\mathrm{AB}}$ & $51.7 \pm 2.0^{\mathrm{B}, \mathrm{a}}$ \\
& Triladyl & $67.5 \pm 2.9^{\mathrm{AB}}$ & $78.7 \pm 3.6^{\mathrm{A}}$ & $75.5 \pm 1.9^{\mathrm{A}}$ & $70.9 \pm 3.8^{\mathrm{A}}$ & $64.4 \pm 5.8^{\mathrm{B}, \mathrm{b}}$ \\
VCL $(\mu \mathrm{m} / \mathrm{s})$ & BF5F & $124.9 \pm 4.6^{\mathrm{A}}$ & $121.9 \pm 5.1^{\mathrm{A}}$ & $120.6 \pm 3.5^{\mathrm{A}}$ & $118.4 \pm 5.2^{\mathrm{A}}$ & $94.4 \pm 1.5^{\mathrm{B}, \mathrm{a}}$ \\
& Triladyl & $119.0 \pm 4.3^{\mathrm{A}}$ & $132.4 \pm 3.3^{\mathrm{B}}$ & $123.1 \pm 3.7^{\mathrm{AB}}$ & $123.0 \pm 3.8^{\mathrm{AB}}$ & $117.3 \pm 5.1^{\mathrm{AB}, \mathrm{b}}$ \\
VSL $(\mu \mathrm{m} / \mathrm{s})$ & BF5F & $68.0 \pm 5.3^{\mathrm{A}, \mathrm{b}}$ & $70.0 \pm 5.7^{\mathrm{A}}$ & $64.5 \pm 4.3^{\mathrm{A}}$ & $62.3 \pm 4.8^{\mathrm{A}}$ & $44.8 \pm 2.1^{\mathrm{B}}$ \\
& Triladyl & $53.2 \pm 4.5^{\mathrm{A}, \mathrm{a}}$ & $68.4 \pm 5.2^{\mathrm{B}}$ & $66.3 \pm 3.1^{\mathrm{AB}}$ & $62.0 \pm 5.1^{\mathrm{AB}}$ & $53.9 \pm 6.7^{\mathrm{AB}}$ \\
LIN $(\%)$ & BF5F & $54.3 \pm 3.2^{\mathrm{AB}, \mathrm{a}}$ & $57.7 \pm 3.0^{\mathrm{A}}$ & $54.2 \pm 3.1^{\mathrm{AB}}$ & $52.6 \pm 2.3^{\mathrm{AB}}$ & $47.7 \pm 1.7^{\mathrm{B}}$ \\
& Triladyl & $45.0 \pm 2.9^{\mathrm{A}, \mathrm{b}}$ & $52.2 \pm 4.2^{\mathrm{AB}}$ & $55.0 \pm 3.7^{\mathrm{B}}$ & $51.2 \pm 4.0^{\mathrm{AB}}$ & $46.6 \pm 3.7^{\mathrm{AB}}$ \\
STR $(\%)$ & BF5F & $85.1 \pm 2.6^{\mathrm{a}}$ & $88.0 \pm 1.9^{\mathrm{A}}$ & $86.4 \pm 2.6$ & $87.2 \pm 1.6$ & $84.2 \pm 1.4$ \\
& Triladyl & $75.1 \pm 4.0^{\mathrm{A}, \mathrm{b}}$ & $84.4 \pm 3.5^{\mathrm{B}}$ & $86.3 \pm 2.9^{\mathrm{B}}$ & $84.9 \pm 3.4^{\mathrm{B}}$ & $81.3 \pm 3.1^{\mathrm{AB}}$ \\
ALH $(\mu \mathrm{m})$ & BF5F & $5.1 \pm 0.2^{\mathrm{A}}$ & $4.8 \pm 0.2^{\mathrm{AB}}$ & $4.9 \pm 0.3^{\mathrm{AB}}$ & $4.7 \pm 0.1^{\mathrm{AB}}$ & $4.2 \pm 0.2^{\mathrm{B}, \mathrm{a}}$ \\
& Triladyl & $5.8 \pm 0.2^{\mathrm{A}}$ & $5.6 \pm 0.5^{\mathrm{AB}}$ & $4.9 \pm 0.4^{\mathrm{B}}$ & $5.0 \pm 0.4^{\mathrm{AB}}$ & $5.2 \pm 0.3^{\mathrm{AB}, \mathrm{b}}$ \\
BCF $(\mathrm{Hz})$ & BF5F & $29.7 \pm 1.6$ & $32.2 \pm 1.2$ & $32.8 \pm 2.2$ & $31.7 \pm 0.7$ & $32.8 \pm 1.4$ \\
& Triladyl & $37.4 \pm 11.8$ & $29.3 \pm 1.4$ & $29.2 \pm 1.5$ & $32.8 \pm 1.6$ & $30.4 \pm 1.3$ \\
\hline Values & & & & & \\
\hline
\end{tabular}

Values represent mean \pm SEM.

${ }^{\text {A, B }}$ Significant differences within a cryodiluent $(P<0.05)$.

${ }^{\mathrm{a}, \mathrm{b}}$ Significant differences between cryodiluents $(P<0.05)$. 
Figure 1.

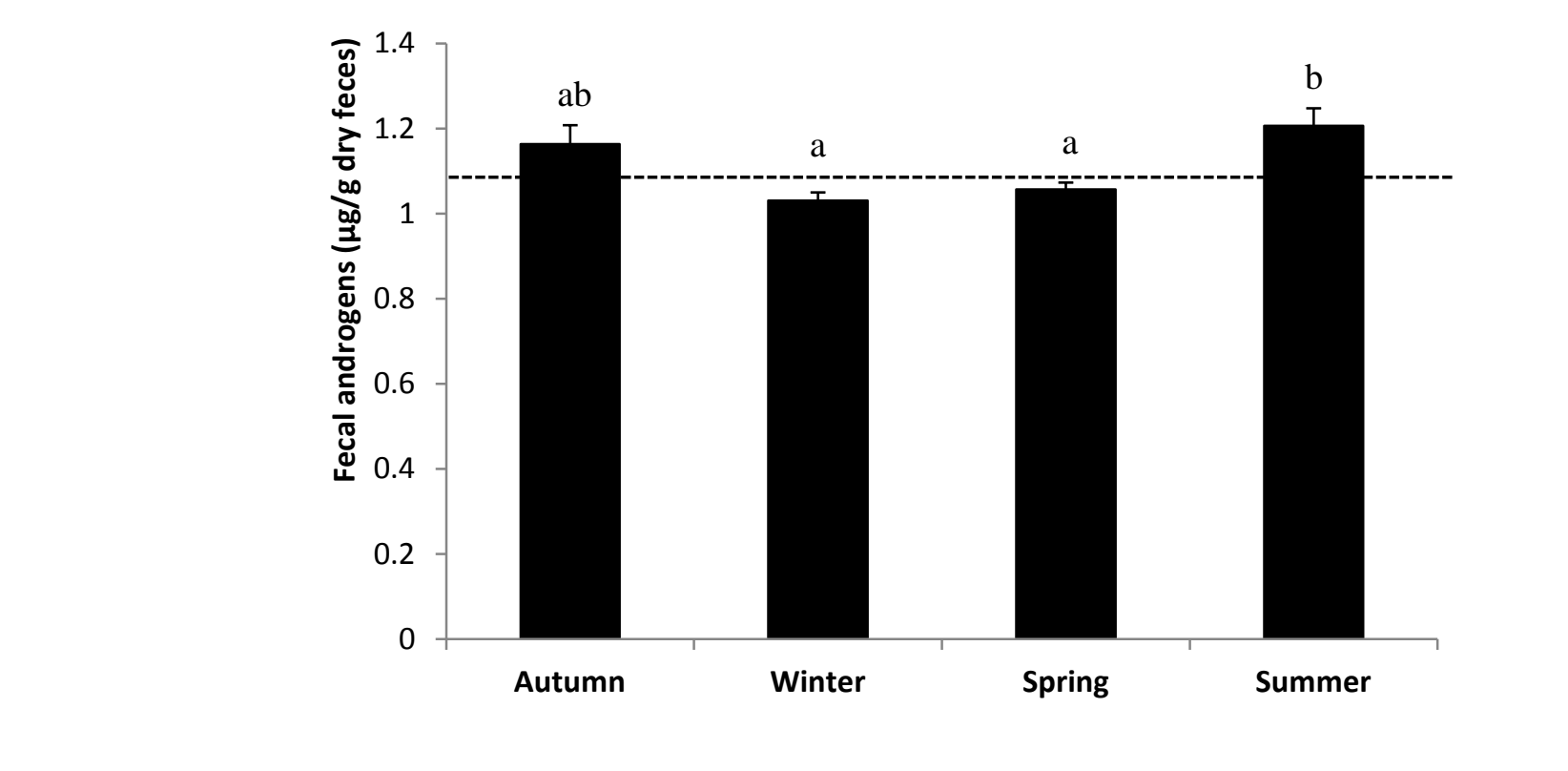

Figure 1

Figure 1.

$\left(\frac{10}{20}\right.$

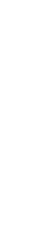

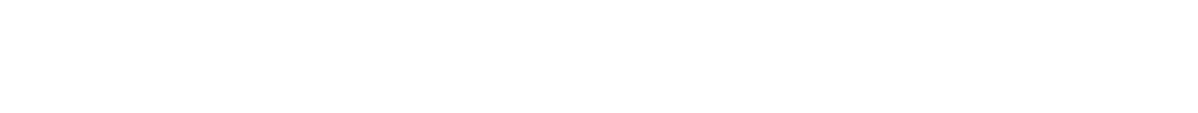

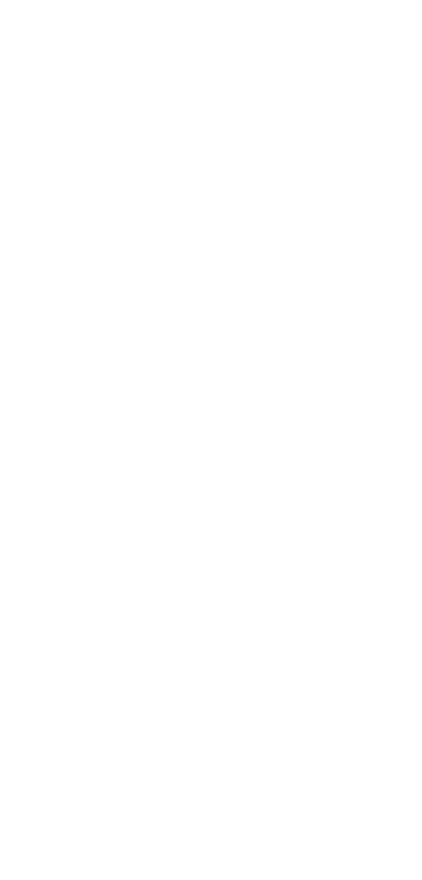

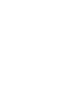


Figure 2.
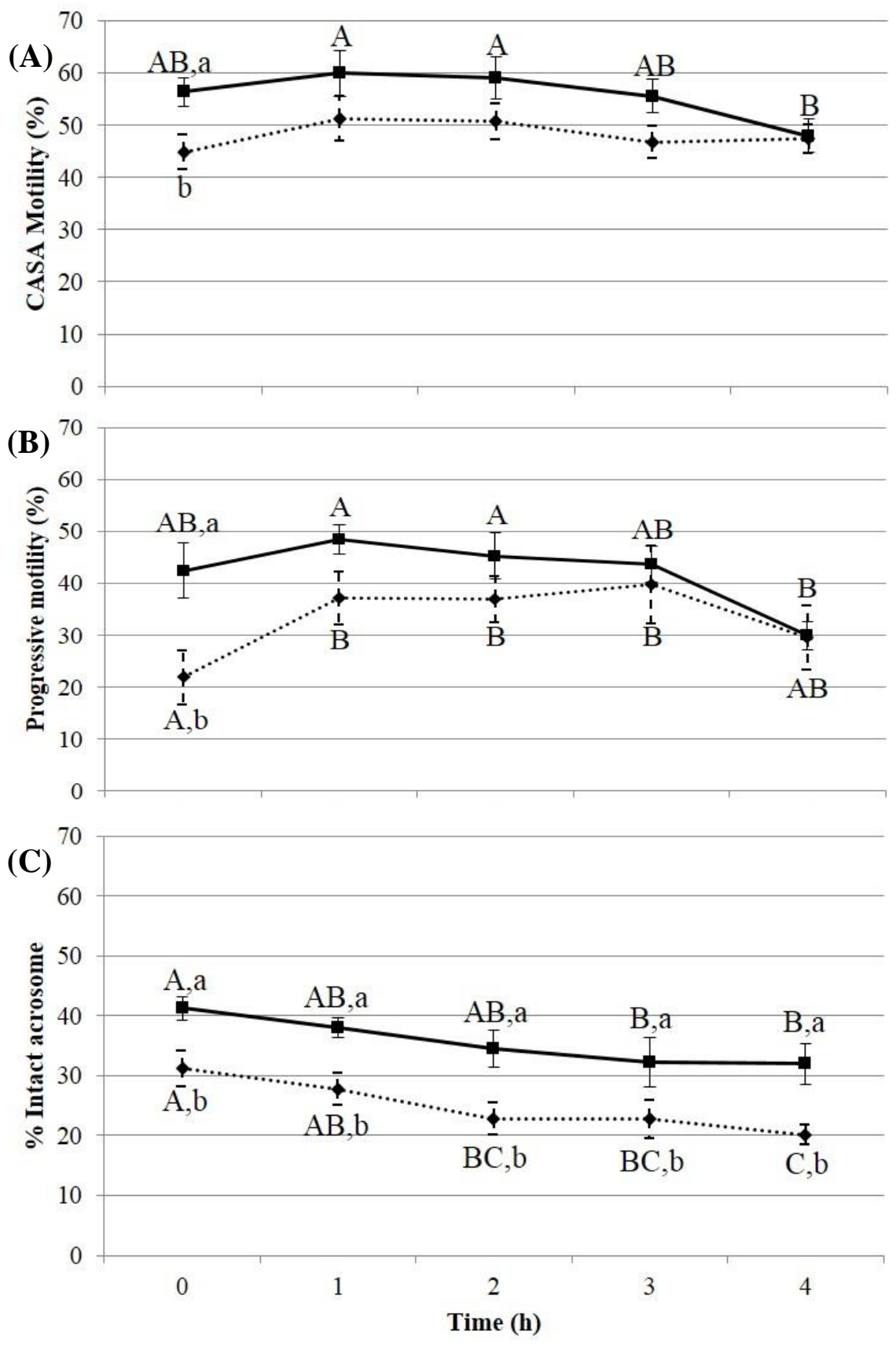